\title{
Evaluation of New Bacteriocin as a Potential Short-Term Preservative for Goat Skin
}

\author{
J. Kanagaraj ${ }^{1, *}$, A. Tamil Selvi ${ }^{2}$, T. Senthilvelan ${ }^{1, *}$, N. K. Chandra Babu ${ }^{1}$, B. Chandrasekar ${ }^{2}$ \\ ${ }^{1}$ Leather Processing Division, Central Leather Research Institute, Adyar, Chennai, India \\ ${ }^{2}$ CHORD, Central Leather Research Institute, Adyar, Chennai, India \\ *Corresponding author: mtsenthil85@yahoo.com
}

Received October 29, 2013; Revised February 09, 2014; Accepted April 29, 2014

\begin{abstract}
Common salt (sodium chloride) and chemical preservatives are used for preservation of skins and leather to protect from microbial attacks, which leads to severe pollution problem. Bacteriocin is an eco-friendly option for skin and leather preservation in leather industry, which contains antimicrobial and antifungal components their fluid. Bacteriocin was extracted from Lactobacillus plantarum isolated from chicken meat by submerged fermentation method. The bacteriocin was tested against the skin putrefying organism Pseudomonas aeruginosa and Bacillus putrefaciens by plate assay method, which showed the activity of $200 \mathrm{AU} / \mathrm{ml}$ for Pseudomonas aeruginosa, and $340 \mathrm{AU} / \mathrm{ml}$ for Bacillus putrefaciens. These two cultures were further analysed by SEM, which showed cleavage of bacterial cell walls due to action of bacteriocin. This study revealed the presence of antimicrobial activity in bacteriocin. Then the bacteriocin was tested for preservation of goat skin infected by skin putrefying organisms of Pseudomonas aeruginosa and Bacillus putrefaciens, and its efficacy was studied. The microbial infected goat skin was preserved with $15 \%$ bacteriocin solution and stored for seven days at room temperature, which showed the complete inhibition of microbial growth even after seven days of storage. Then the goat skin was further processed into crust leather and which was analysed by SEM and physical testing data. The SEM analysis and physical testing data revealed no significant changes in the fiber structure of the skin due to preservation by bacteriocin. The pollution load generation (Total Dissolved solvents) has reduced at the level of $94.4 \%$ and $95.6 \%$ (of chlorides) during soaking process. The overall experiments revealed that the bacteriocin can be used as potential bio preservatives for preservation of skin and leather.
\end{abstract}

Keywords: Lactobacillus plantarum, bacteriocin, goat skin preservation, SEM analysis, pollution reduction

Cite This Article: J. Kanagaraj, A. Tamil Selvi, T. Senthilvelan, N. K. Chandra Babu, and B.Chandrasekar, "Evaluation of New Bacteriocin as a Potential Short-Term Preservative for Goat Skin." American Journal of Microbiological Research, vol. 2, no. 3 (2014): 86-93. doi: 10.12691/ajmr-2-3-2.

\section{Introduction}

Leather industry is using plenty of toxic chemicals for leather processing operation, which leads to severe pollution problem and also facing many problems like high production cost, lack of skilled labor, electricity demand and microbial attacks on skins/hide/leather due to following poor storage techniques. In earlier days, the leather industry has economically contributed in many developing countries for their growth. But presently the leather industry is unable to make more profit due to spending lot of money for treatment of wastes generated from leather processing operation. Because the untreated leather chemical wastes are spoiling the land fertility, aquatic life of the organism and breathing problem due to odor, which is discharged into environment. So, the leather industry needs the changes to replace the chemical usage in leather processing operation to minimize the pollution load generation in the environment. Leather industry is now adapted for microbial enzyme based leather processing operation, which is the viable alternative for chemical method and also minimized amount of pollution load generation in the environment. The microbial enzyme such as protease, lipase, xylenase are used in leather processing operation, which attracts the tanners in good manner.

The skins and hides are the very important raw material for leather processing operation $[1,2]$. The raw materials are preserved by enormous amount of salt (sodium chloride) after immediate flying house operation to prevent from decomposition and skin putrefying organism such as Bacillus cereus, Bacillus putrefaciens, Bacillus subtilis, Bacillus mesenthericus, Micrococus rubescens, Pseudomonas aeruginosa, Penicillium sp. and Aspergillus niger. The salted skin and hide was removed before processing into leather by soaking into water, which leads to higher Total Dissolved Solids (TDS) in the waste water [3]. The salt is discharged mainly from salt curing, pickling, and chrome tanning operation but mostly from curing stage. The leather industry is contributing $40 \%$ of TDS and $55 \%$ of chlorides in the effluents. So, the additional investment need for removal of TDS in the waste water. Sodium chloride is very difficult to remove and also cause problems to the effluent treatment. 
According to pollution control board norms the TDS must be $2100 \mathrm{mg} / \mathrm{L}$ in the treated leather waste water $[4,5]$. Leather industry is still having lack of preservation technology to preserve the skins/hides without salt (sodium chloride). So, the industry is very much needing eco-friendly alternative technology for preservation of leather raw materials. Therefore development of a viable alternative preservation system is the need of the hour for protecting leather industry from environmental issues. The present research is focusing on using bacteriocin as an effective bio-preservative to preserve the skin without any harmful effect to living beings.

Bacteriocin is prepared for skin/hide and leather preservation, because it contains antimicrobial and antifungal active compounds in its fluids and which is ribosomally synthesized bactericidal peptides and are produced by few microorganisms in all major lineages of Eubacteria and Archaebacteria. Bacteriocins are low molecular weight, cationic, amphophilic molecules [6]. Bacteriocin is already current in use for food preservation to prevent the food material from food spoiling microbes for long term storage. Lactic acid bacteria (LAB) are capable of inhibiting various microorganisms in a food environment and display crucial antimicrobial properties with respect to food preservation and safety [7]. In this present investigation, the principle of inhibiting various micro organisms of LAB to the leather is explored. The bacteriocin produced from the Lactobacillus plantarum was characterized and then studied for preservation of goat skin in the place of conventional sodium chloride method. In the conventional method, sodium chloride at the level of $40-50 \%$ (based on skin wet weight) is applied to preserve the skins. But in the current study at the level of $15 \%$ of bacteriocin was used for preservation of skin/hide/leather based on the weight.

Bacteriocin is used as preservatives in various industries to stabilize the end products. The application of bacteriocin is already tested in food, pharmaceutical, and fermentation industry only. But the current involves application of bacteriocin to leather industry for preservation of skins/hides and leather preservation. The new attempt was made first time in leather industry. It is very much clear from the above discussion that treatment cost of waste using bacteriocin does not require any additional investment and technology for the treatment of effluent whereas the salt treated effluent liquor requires solar evaporation pan or other membrane treatment for treatment of wastes.

\section{Materials and Methods}

\subsection{Goat Skin Samples Collection}

Goat skin samples were collected after immediate slaughter house operation and all skin samples were kept inside on sterile plastic bags and immediately transported to laboratory and stored at room temperature for 1-3 days. The all chemicals and microbiological media were used in this study was purchased from Sigma-Aldrich chemicals and Hi-Media, in Mumbai, India.

Some of the following skins putrefying microbial sp. were isolated from the fresh goat skins, bacteria such as Bacillus cereus, Bacillus putrefaciens, Bacillus subtilis,
Bacillus Mesenthericus, Micrococus rubescens, Pseudomonas aeruginosa, Penicillium sp. and fungi such as Aspergillus niger. But Bacillus putrefaciens and Pseudomonas aeruginosa were considered for the further studies.

\subsection{Isolation of Potential Lactic Acid Bacteria (LAB) from Various Meats}

The various raw materials used for isolation of Lactic acid bacteria (LAB) were chicken intestine, chicken meat, fish meat, fish entrails and were procured from local market of Chennai. The LAB isolation procedure was as follows: $10 \mathrm{~g}$ of meat sample were homogenized and dissolved in $90 \mathrm{ml}$ of saline sample to make up $10^{-1}$ dilution. The $10 \mathrm{ml}$ of homogenized sample was poured on MRS agar medium by pour-plate method and the plates were incubated at $37^{\circ} \mathrm{C}$ for $24-48 \mathrm{~h}$. Some of the colonies were selected and sub cultured in MRS agar medium for $24 \mathrm{~h}$ at $37^{\circ} \mathrm{C}$. The mother inoculums were stored at $6^{\circ} \mathrm{C}$ in MRS agar medium and sub cultured at regular intervals of 30 days. Isolated cultures were identified by biochemical tests and staining techniques [8,9]. The catalase test reaction was visualized through Phase Contrast Microscopy.

\subsection{Production and Purification of Bacteriocin}

The isolated $\mathrm{LAB}$ was inoculated in to conical flak containing $500 \mathrm{ml}$ of MRS broth incubated at $37^{\circ} \mathrm{C}$ for 36 h. The culture was centrifuged at $1000 \mathrm{rpm}$ for $10 \mathrm{~min}$ and supernatant was taken and further partially purified by precipitation method by using Ammonium sulfate followed by dialysis and gel filtration chromatography [10]. Bacteriocin protein concentrate was estimated by Bradford (1976) method.

\subsection{Effect of Bacteriocin against Enzyme Treatment}

Bacteriocin was tested against various proteolytic (Trypsin, Pepsin, Papain) and non-proteolytic ( $\alpha$ - Amylase, Lipase) enzymes. For this study; aliquot containing $0.5 \mathrm{ml}$ of the concentrated bacteriocin was incubated for $24 \mathrm{~h}$ at $37^{\circ} \mathrm{C}$ with the following enzymes at $10 \mathrm{mg} / \mathrm{ml}$ concentration; (i) Trypsin (ii) Pepsin (iii) Papain (iv) $\alpha$ Amylase (v) Lipase. All the enzyme activities were measured after treatment with bacteriocin by using respective substrates.

\subsection{Isolation of Skin Putrefying Bacteria from Goat Skins}

For isolation of skin putrefying organisms, the skin samples were gently parted and staple cut into $5 \times 5 \mathrm{~cm}$ pieces in aseptic condition and added to a $500 \mathrm{ml}$ conical flask containing $100 \mathrm{ml}$ of sterile physiological saline $(0.85 \% \mathrm{NaCl})$. The samples were agitated and serially diluted before streaking into petriplates containing plate count agar medium, Nutrient Agar medium and LB agar medium. The plates were incubated at $30^{\circ} \mathrm{C}$ for $1-5$ days and discrete colonies with different morphological characteristics were picked up from the petriplates and sub cultured, stored at $-4^{\circ} \mathrm{C}$ as pure culture [11]. 


\subsection{Evaluation of Antibacterial Activity of Bacteriocin by Plate Assay Method}

The isolated bacterial cultures from goat skin were grown in nutrient broth for $24 \mathrm{~h}$ at $37^{\circ} \mathrm{C}$. Then nutrient agar medium was prepared and poured into the petriplates and appropriate numbers of wells were made after solidification. $60 \mu \mathrm{l}$ of bacteriocin was added into each well and pre-incubated at $4^{\circ} \mathrm{C}$ for $2-3 \mathrm{~h}$ to allow the bacteriocin to diffuse into the agar medium and then the $24 \mathrm{~h}$ nutrient broth culture was taken and swabbed on the nutrient agar plates. The plates were further incubated for $18 \mathrm{~h}$ at $37^{\circ} \mathrm{C}$ and examined for zone of clearance around the individual wells [12]. The diameter of the zone of clearance, if any thus formed, was measured in arbitrary units per $\mathrm{ml}(\mathrm{AU} / \mathrm{ml})$ from the volume taken in the well ( $\mu \mathrm{l})$.

$$
A U / m l=\frac{\text { Diameter of the of zone clearance }(\mathrm{mm}) \times 1000}{\text { Volume taken in the well }(\mu \mathrm{l})}
$$

\subsection{Scanning Electron Microscopy (SEM) Observation of Bacteriocin Treated Skin Putrefying Bacterial Culture}

Purified bacteriocin was added to $10^{-4}$ dilution of bacterial cells and incubated at $37^{\circ} \mathrm{C}$ for $24 \mathrm{~h}$. After incubation, the cells were centrifuged at $6000 \mathrm{rpm}$ for 15 min and washed twice with $0.01 \mathrm{M}$ Potassium phosphate buffer ( $\mathrm{pH}$ at 7.0). The samples obtained in the form of pellets after centrifugation at $6000 \mathrm{rpm}$ were cross-linked with $2 \%$ Glutaraldehyde for $2 \mathrm{~h}$ at $4^{\circ} \mathrm{C}$. The pellet thus obtained was dehydrated in a gradient ethanol (10-100\%). Initially, 40\% ethanol was used and centrifuged and then the cells were transferred onto the slide and subsequently treated with $100 \%$ ethanol. The slides were then dried in desiccators. The control and treated samples were poured in $\mathrm{BHI}$ agar and incubated at $37^{\circ} \mathrm{C}$ for $24 \mathrm{~h}$ and then the samples were subjected to SEM studies. The growth was observed visually after incubation.

\subsection{Bacteriocin Application for Goat Skin Preservation}

Freshly stripped goat skins (commercial levels) were taken for the experiment and made it two halves. The left halves (experimental samples) were immersed in various conc. of bacteriocin solution $(0.1,1,2,3,4,5,10,15$ and $20 \%$ ) and right halves were treated with salt at the level of $40 \%$ on the green weight, which serves as a control. The experimental and control skin samples were folded and stored at an ambient temperature for 1 week. $100 \mathrm{~g}$ of skin samples were taken from each control and experimental samples and were cut into small pieces and soaked well in the sterile water in different beakers containing $250 \mathrm{ml}$ of sterile water. The soaking water was inoculated into nutrient agar plates after serially diluted by $10^{-3}$ to $10^{-9}$ and kept for incubation at $37^{\circ} \mathrm{C}$. The organism growth was observed on nutrient agar plates after $24 \mathrm{~h}$ incubation time [13].

\subsection{Physical Strength Properties of Bacteriocin Treated Leather}

The preserved skins sample of both the control and experiment were processed to crust leathers in accordance with normal tanning practices and then tested for their physical strength properties. The crust leather was conditioned at a temperature of $20^{\circ} \mathrm{C}$ and $65 \%$ at relative humidity over a period of $48 \mathrm{~h}$ before measurement. The leather properties such as tensile strength, elongation at break, tear strength and grain crack were measured in an Instron tensile testing machine (BIS standards). Leather quality was also visually inspected and graded by experts, who are working in leather processing division at Central Leather Research Institute, Chennai, in India.

\subsection{Scanning Electron Microscopic (SEM) Analysis}

The SEM analysis was carried out for order to verify the fiber structure of leather free from bacterial attack. The control and bacteriocin treated crust leather sample was cut into $5 \mathrm{~mm} \times 2 \mathrm{~mm}$ size from the official butt portion were subjected to SEM studies to assess the effect of bacteriocin on the grain surface and fiber orientation in the cross section of leather. A JOEL JSM 5300 scanning electron microscope was used to study the cross section of the leather.

\subsection{Measurement of Pollution Load}

The pollution load generation such as biochemical oxygen demand (BOD), chemical oxygen demand (COD), total dissolved solvent (TDS) and chlorides (Cl) were measured from spent liquor of experiment (after treatment of bacteriocin) and control skin samples [14].

\section{Results}

\subsection{Isolation and Identification of Lactic Acid Bacteria (LAB)}

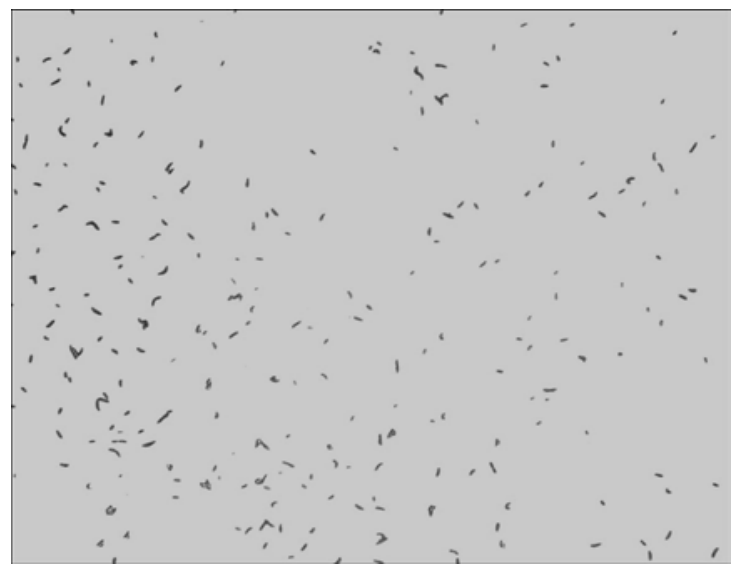

Figure 1. Lactobacillus plantarum rods viewed by Phase Contrast Microscope

The twenty LAB cultures were isolated from various meat products and four LABs were found to have bacteriocin activity among twenty cultures [15]. One LAB culture showed maximum bacteriocin activity compared to other three LAB culture. Hence, that particular strain was taken for further studies, which is identified as Lactobacillus plantarum. The Lactobacillus plantarum is rod shaped lactic acid bacteria viewed by Phase Contrast 
Microscope (Figure 1). The Lactobacillus plantarum was used for bacteriocin production, which showed the maximum bactiocin activity of 470 units/ml at the $\mathrm{pH} 4.5$, temperature at $40^{\circ} \mathrm{C}$ and the duration of $48 \mathrm{~h}$.

\subsection{Purification and Protein Estimation of Bacteriocin}

The bacteriocin showed 35.60 fold and 1.76 fold of purification respectively for both gel-filtration Chromatography method and ammonium sulfate precipitation method. The protein content of the bacteriocin was measured after purification; the conc. of protein is $0.55 \mathrm{mg}$ for purified by gel-filtration Chromatography and $0.50 \mathrm{mg}$ for ammonium sulfate precipitation method (Table 1).

Table 1. Purification of bacteriocin

\begin{tabular}{|c|c|c|c|c|c|c|c|c|}
\hline Purification steps & $\begin{array}{c}\text { Volume } \\
(\mathrm{ml})\end{array}$ & $\begin{array}{c}\text { Activity } \\
(\mathrm{AU} / \mathrm{ml})\end{array}$ & $\begin{array}{c}\text { Total Activity } \\
(\mathrm{AU})\end{array}$ & $\begin{array}{c}\text { Protein } \\
(\mathrm{mg} / \mathrm{ml})\end{array}$ & $\begin{array}{c}\text { Total protein } \\
(\mathrm{mg})\end{array}$ & $\begin{array}{c}\text { Specific activity } \\
(\mathrm{AU} / \mathrm{mg} \text { protein) }\end{array}$ & $\begin{array}{c}\text { Activity } \\
\text { Recovery (\%) }\end{array}$ & $\begin{array}{c}\text { Purification } \\
\text { Fold }\end{array}$ \\
\hline Crude bacteriocin & 50 & 310 & 15500 & 11 & 55 & 25 & 100 & 1 \\
\hline $\begin{array}{c}\text { Ammonium Sulfate } \\
\text { precipitation method }\end{array}$ & 5 & 400 & 2100 & 12 & 0.50 & 44 & 14 & 1.76 \\
\hline $\begin{array}{c}\text { Gel Filtration } \\
\text { Chromatography }\end{array}$ & 1 & 500 & 500 & 0.55 & 0.55 & 890 & 3.33 & 35.60 \\
\hline
\end{tabular}

\subsection{Evaluation of Bacteriocin Activity against Enzymes}

The bacteriocin was applied against various enzymes such as Pepsin, Trypsin, $\alpha$-amylase, Lipase and Papain. Bacteriocin lost the activity against almost all the enzymes, which indicates presence of glycopeptides in the bacteriocin and carbohydrate moiety may also be associated with its activity (Table 2). The residual activity of Trypsin is $68 \%$ (lost the activity of $32 \%$ ), similarly the proteases enzymes such as Pepsin and Papain showed the residual activity of 56 and 54\% respectively against bacteriocin. The protease enzyme showed less enzymatic activity compared to other enzymes. The Lipase and $\alpha$ amylase showed the residual activity of 98 and $100 \%$ respectively.

Table 2. Effect of enzymes on bacteriocin activity
\begin{tabular}{|c|c|c|}
\hline S.No & Enzymes & Residual Activity (\%)* \\
\hline 1 & Trypsin & 68 \\
\hline 2 & Pepsin & 56 \\
\hline 3 & $\alpha$-Amylase & 100 \\
\hline 4 & Lipase & 98 \\
\hline 5 & Papain & 54 \\
\hline
\end{tabular}

*Residual activity compared with antimicrobial activity before the treatment.

Results are means of three individual assays with SD less than 5\% about the mean.

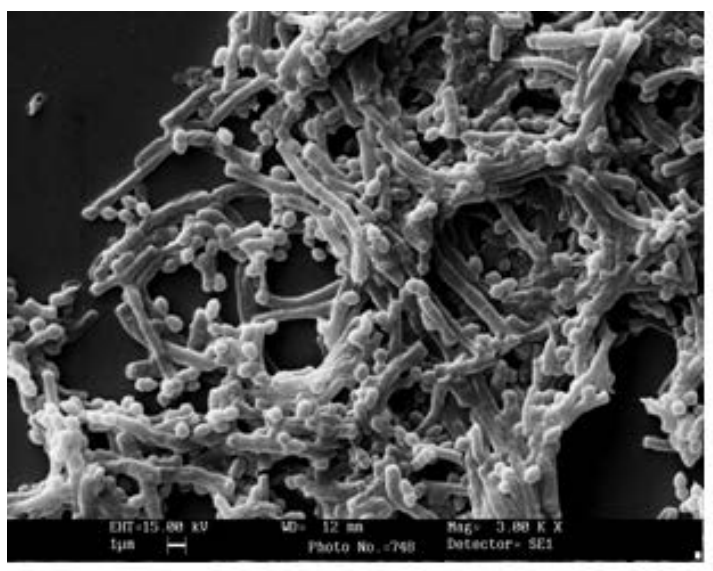

a)

\subsection{Antagonist Activity Associated with Bacteriocin}

LAB cultures isolated from various meat products exhibited a broad spectrum of antimicrobial activity against various bacteria. The bacteriocins from the LAB are potent in inhibiting organisms [16]. Thus remarkable activity of bacteriocin was observed against 8 organisms obtained from goat skin. It can be seen from results that the antimicrobial activity of bacteriocin against the Pseudomonas aeruginosa and Bacillus putrefaciens were recorded $200 \mathrm{AU} / \mathrm{ml}$ and $340 \mathrm{AU} / \mathrm{ml}$ respectively for both organisms.

\subsection{Antibacterial Activity Associated with Bacteriocin by SEM Analysis}

An attempt was made to observe the morphological changes in the bacteriocin treated cells of target microorganism by SEM analysis (Figure 2). In this experiment the bacterial colonies obtained from goat skin were used as the target microorganisms. The SEM images show the appearance of complete lysis of bacterial cell wall [17], which confirms the antibacterial activity of bacteriocin against skin putrefying microorganisms (Figure 3). So the bacteriocin can be prepared for preservation of skin and leather in leather industry and which will minimize the pollution load generation by replacing the chemical preservatives.

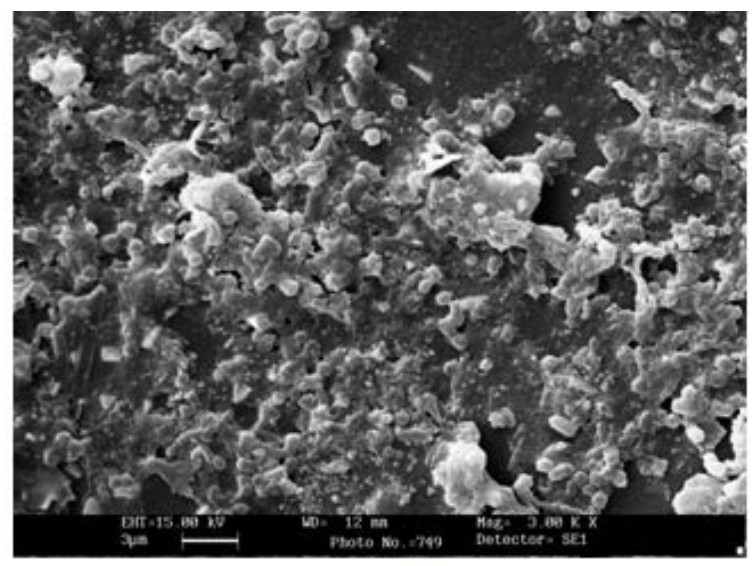

b)

Figure 2. (a) Scanning electron micrographs of Bacillus cereus control (b) Scanning Electron Micrographs of Bacillus cereus treated with partially purified bacteriocins 


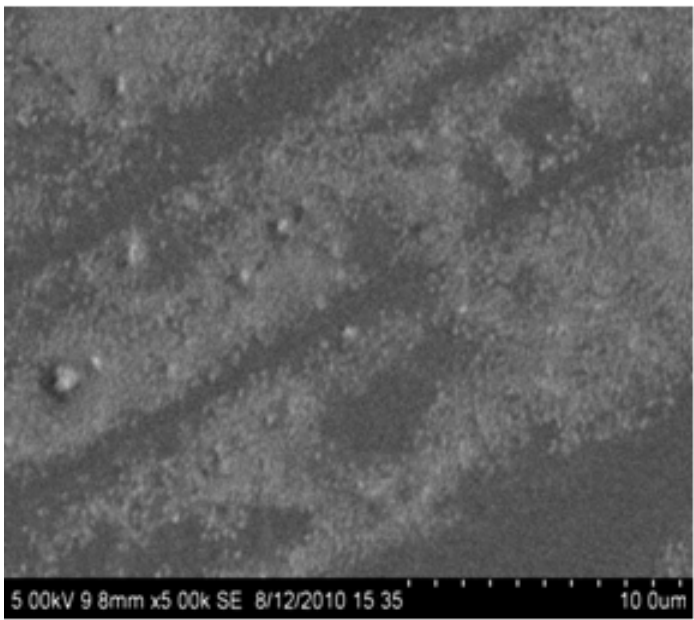

a)

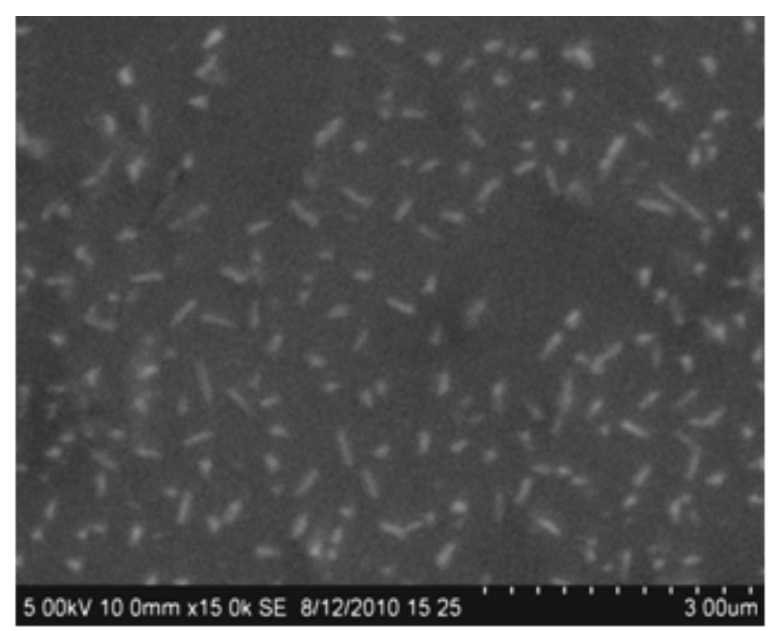

b)

Figure 3. SEM Photographs of the bacteriocin treated bacterial cells. a) Control samples (b) Experiment

\subsection{Preservation of Goat Skin by Bacteriocin}

Table 3. Antibacterial activity of bacteriocin against microbial consortium on goat skin

\begin{tabular}{|c|c|}
\hline Sample & CFU cm $^{-2}$ \\
\hline Control (without any treatments) & $2.8 \pm 0.3 \times 10^{8}$ \\
\hline Control (Nacl-50\%) & $1.8 \pm 0.5 \times 10^{3}$ \\
\hline Bacteriocin- 1\% & $2.6 \pm 0.6 \times 10^{8}$ \\
\hline Bacteriocin- 2\% & $1.9 \pm 0.6 \times 10^{4}$ \\
\hline Bacteriocin-3\% & $6.6 \pm 0.3 \times 10^{3}$ \\
\hline Bacteriocin- 4\% & $1.4 \pm 0.3 \times 10^{2}$ \\
\hline Bacteriocin- 5\% & $1.0 \pm 0.1 \times 10^{2}$ \\
\hline Bacteriocin- 10\% & $1.0 \pm 0.1 \times 10^{1}$ \\
\hline Bacteriocin- 15\% & No growth \\
\hline Bacteriocin- 20\% & No growth \\
\hline
\end{tabular}

The goat skins containing various bacterial growth was preserved by bacteriocin at various concentrations level (1, 2, 3, 4, 5, 10, 15 and 20\%) and was stored for 7 days. Then the skin bacteria (viable only) was counted after storage, which is given in Table 3. It is observed from the table, the CFU $\mathrm{cm}^{-2}$ is reduced to the level of $1.0 \pm 0.1 \times$ $10^{1}$ for the skin that was treated with $10 \%$ bacteriocin. The skin treated with bacteriocin at the level of 15 and $20 \%$ shows no growth of colony and this is one of the reason that bacteriocin is used as a preservative in skin preservation. The pollution load generated from bacteriocin treated skins shows reduction of pollution loads at huge level. The Table 4 shows the comparison of pollution load generation in both bacteriocin treated and salt treated skins. The table shows the reduction of TDS at the level of $94.4 \%$ and Chlorides at the level of $95.6 \%$ in soaking process in bacteriocin treated skin sample. The reduction of pollution load is excellent in the experimental sample over control sample. The experiments were optimized and the results were studied in a larger scale and discussed in a detailed manner.

Table 4. Comparison of pollution load generation during soaking operations for bacteriocin treated and salt treated skin

\begin{tabular}{|c|c|c|}
\hline \multirow{2}{*}{ Pollution Parameters } & \multicolumn{2}{|c|}{ Pollution load (ppm) } \\
\cline { 2 - 3 } & $\begin{array}{c}\text { Bacteriocin } \\
\text { treated skin }\end{array}$ & $\begin{array}{c}\text { Salt treated } \\
\text { skin }\end{array}$ \\
\hline Bio-Chemical Oxygen Demand (BOD) & 1150 & 1560 \\
\hline Chemical Oxygen Demand (COD) & 1690 & 2820 \\
\hline Total Dissolved Solids (TDS) & 1210 & 17500 \\
\hline Chlorides (cl) & 460 & 10,170 \\
\hline
\end{tabular}

\subsection{Replication of Present Approach}

The bacteriocin was prepared at larger quantity by using fermenter and the preservation experiments were carried out. Table 5 shows various preservation experiments with bacteriocin and the properties of skin during preservation period. It is seen from the table that the skin treated with bacteriocin at $15 \%$ shows negative factor of hair slip at some places but with positive factors of putrefaction odor, easy rehydration in soaking. The other experiments carried out with bacteriocin at 20\% show no hair slip and positive factors of the above mentioned properties. It is confirmed that bacteriocin at $20 \%$ is very much needed to inhibit the skin isolates for the preservation of skin. Hence bacteriocin at $20 \%$ is optimized for commercial scale and the experiments were repeated and the leather qualities were studied. The skins were further processed into crust leathers.

Table 5. Various preservation experiments with bacteriocin and the properties of skin during preservation

\begin{tabular}{|c|c|c|c|c|}
\hline \multirow{2}{*}{ S.No } & \multirow{2}{*}{ Experiments } & \multirow{2}{*}{ Quantitry of Bacteriocin } & \multicolumn{2}{|c|}{ Properties of skin } \\
\hline & & & (-)ve findings & (+)ve findings \\
\hline 1 & Experiment 1 & $15 \%$ & \multirow{3}{*}{$\begin{array}{l}\text { No grain damage, No putrefaction } \\
\text { odor, Easy rehydration in soaking }\end{array}$} & \multirow{3}{*}{ Hair slip found at some places } \\
\hline 2 & Experiment 2 & $15 \%$ & & \\
\hline 3 & Experiment 3 & $15 \%$ & & \\
\hline 4 & Experiment 4 & $20 \%$ & \multirow{3}{*}{$\begin{array}{l}\text { No hair slip, No grain damage, No } \\
\text { putrefaction odor, Easy rehydration in } \\
\text { soaking }\end{array}$} & \multirow{3}{*}{ None } \\
\hline 5 & Experiment 5 & $20 \%$ & & \\
\hline 6 & Experiment 6 & $20 \%$ & & \\
\hline
\end{tabular}


Table 6. Leather quality in terms of visual assessment by 10 point ratings

\begin{tabular}{|c|c|c|c|c|}
\hline \multirow{2}{*}{ Properties } & \multicolumn{2}{|c|}{ Bacteriocin (20\%) treated leather } & \multicolumn{2}{c|}{ Salt (50\%) treated leather } \\
\cline { 2 - 5 } & 10 Point ratings & Properties & 10 Point ratings & Properties \\
\hline Grain Properties & $7 \pm 0.5$ & Grain is smoother & $8 \pm 0.2$ & Grain is tight in structure \\
\hline Softness & $9 \pm 0.3$ & Good softness & $8 \pm 0.5$ & Moderate softness \\
\hline Fullness & $7 \pm 0.5$ & Moderate fullness & $8 \pm 0.3$ & Better fullness \\
\hline Dyeing Property (intensity) & $8 \pm 0.2$ & Uniform in color, uptake is better & $7 \pm 0.5$ & Uniform in color but uptake is moderate \\
\hline Strength & $8 \pm 0.3$ & Good strength & $8 \pm 0.5$ & Good strength \\
\hline General Appearance & $8 \pm 0.5$ & Good & $8 \pm 0.5$ & Good \\
\hline
\end{tabular}

Table 6 shows leather quality in terms of 10 point ratings. The experimental leather produced by bacteriocin treated skin shows good softness, dyeing property, strength as compared to salt produced leather. The experimental samples are able to produce the leather qualities as that of salt treated skin samples. It is clear that bacteriocin treated leather shows comparable leather quality as that of salt preserved leather.

Physical properties of the crust leathers processed from bacteriocins treated skins shows comparable physical

strength properties with those of conventionally salt preserved skin (Table 7). Similarly Figure 4 shows SEM photographs of the leather processed from bacteriocin treated skins. The results show that there is no much difference in the fiber orientation of the experimental and control samples. It confirms that the fibers of the bacteriocin treated skins did not undergo any bacterial degradation. From the above results, it is very clear that there is no putrefaction damage on bacteriocin treated skins.

Table 7. Physical strength properties of bacteriocin treated leather

\begin{tabular}{|c|c|c|c|}
\hline Parameters & Bacteriocin treated skin (Experiment) & Salt treated skin (control) & Minimum requirements \\
\hline Tensile Strength $\left(\mathrm{kg} / \mathrm{cm}^{2}\right)$ & 240 & 220 & 200 \\
\hline Elongation at break (\%) & 67.20 & 62.50 & 40 \\
\hline Tear Strength $(\mathrm{N})$ & 50.20 & 50.10 & 30 \\
\hline Load at grain crack (kg) & 30.10 & 30.20 & 20 \\
\hline Distension at grain crack (mm) & 8.40 & 8.60 & 7 \\
\hline
\end{tabular}

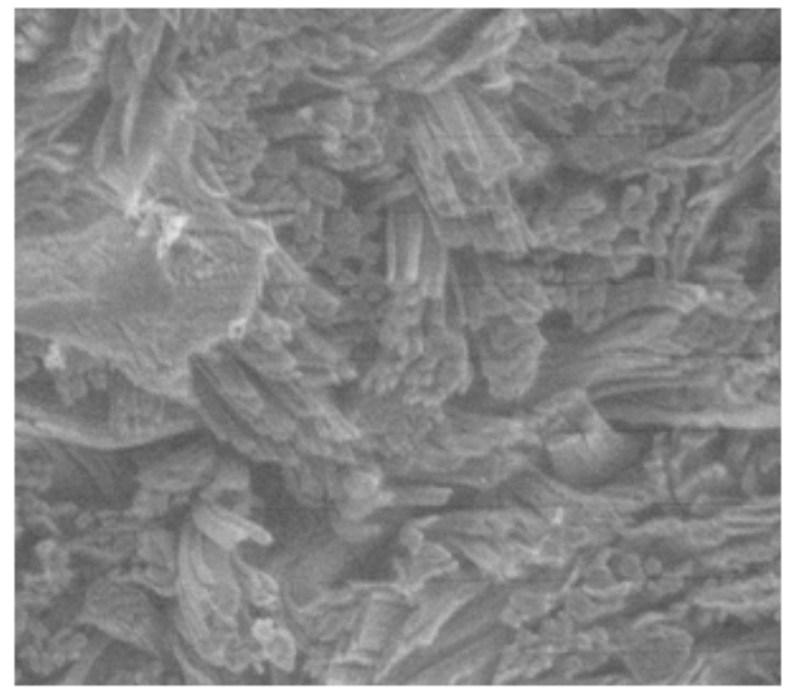

a)

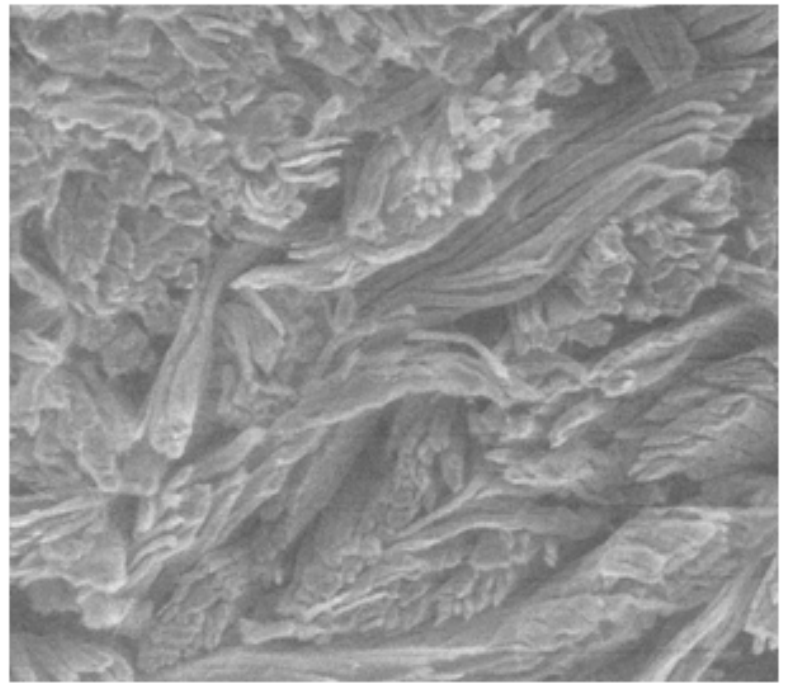

b)

Figure 4. SEM Photographs of the leather preserved by Bacteriocin. a)Experiment, b) Control samples

\subsection{Worker Health Safety while Handling of Bacteriocin}

Bacteriocin is an extracellular fluid, which secretes out from all lactic acid bacteria. The bacteriocin is normally containing antimicrobial activity, which can inhibit the growth of microorganism and is not harmful to any other living beings including human. So, the bacteriocin can be used for leather preservation and handling of bacteriocin for leather preservation did not cause any health problem to the workers. Bacteriocin can trust $100 \%$ safe in health aspects and also no researchers have reported about the toxicity of bacteriocin so far [18].

\section{Discussion}

Most of the bacteriocin producing $\mathrm{LAB}$ was found in meat and meat based food products due to high protein content, so the chicken meat was used as sources for isolation of potential bacteriocin producing organism of Lactobacillus plantarum $[19,20,21,22]$. The Lactobacillus plantarum strain was produced high amount of bacteriocin and was applied for goat skin preservation. The antibacterial activity of bacteriocin has been evaluated against bacterial colonies associated with goat skin. In order to determine the antibacterial efficiency of 
bacteriocin, bacteria were isolated, identified and MICs values of bacteriocin were determined for each isolates $[23,24,25]$. The results are presented in Figure 4. The antimicrobial activity of the isolate obtained from goat skin showed 200AU/ml for Pseudomonas aeruginosa, and 340AU/ml for Bacillus putrefaciens. The maximum activity was recorded for Bacillus putrefaciens.

On evaluating various concentrations of bacteriocins to inhibit the bacterial growth on goat skins, it was found that the goat skins which got immersed in $15 \%$ bacteriocins remained free from bacterial growth even after 7 days storage at room temperature $\left(29^{\circ} \mathrm{C}\right)$. This proves that bacteriocins can be used as preservative for skin preservation [26]. It has been shown that while assessing any preservative material for its efficacy, the preservative need to be bacteriocidal in first place and then bacteriostatic in nature, so that it can inhibit all bacteria from fresh skins as well as during the preservation period of skins. Bacteriocin is very well used to reduce TDS and chloride problem owing to reduction of the same from conventional salt preservation methods. Hence, TDS and chlorides cannot be treated through conventional methods [27,28].

Bacteriocin helps to preserve the goat skins thereby tanneries are able to meet environmental discharge norms set by the authorities for TDS and chlorides by this method [29,30]. Bacteriocin based inhibition of bacterial growth on goat skins will overcome these environmental constraints as it reduces more than $90 \%$ of TDS and chlorides emission in soaking effluent. SEM studies revealed that the leather obtained from bacteriocin treated skin did not show any grain damage and was much better to the goat skin treated with salt indicating that bacteriocin had not affected the quality and texture of the goat skin.

\section{Conclusion}

The primary aim of the work is to establish preservation for goat skin by employing bacteriocin. The treatment process for the pollution problem of TDS and chlorides is very difficult and requires latest technologies. These pollution problems had resulted in closure of many leather industries. There is a need to develop biological method of preservation. The bacteriocin is a biological compound which can be treated very easily in the resulting effluent and therefore the preservation system developed by this method is eco-friendlier one. Bacteriocin also seemed to be cost effective as compared to conventional preservation methods. As a result, bacteriocin has a great potential to emerge as viable alternative for the conventional salt based bacterial inhibition on goat skin which prevents the biodeterioration of goat skin.

The antibacterial activity of bacteriocin against various bacteria obtained from goat skin was remarkable one. The activity of bacteriocin was further confirmed by carrying out SEM studies, which showed that there was a cleavage in the treated bacterial cells suggesting the mechanism of lysis of the bacterial cells. The leather produced by bacteriocin preservation was better in strength properties and also free from any bacterial degradation. The reduction in pollution loads such as TDS and Chlorides was achieved more than $90 \%$ using bacteriocin as treated preservation method.

\section{References}

[1] Kanagaraj J, Chandra Babu NK (2002) Alternatives to salt curing techniques- a review. Journal of Scientific and Industrial Research 61: 339-348.

[2] Kanagaraj J, Chandra Babu NK, Sadulla S, Suseela Rajakumar G, Chandra Kumar N (2001) Cleaner techniques for the preservation of raw goat skin. Journal of Cleaner Production 9: 261-268.

[3] Kanagaraj J, Chandra Babu NK, Sadulla S, Suseela Rajakumar G, Chandra Kumar N (2000) A new approach to less-salt preservation of raw skin/hide. Journal of American Leather Chemical Association 95: 368-374.

[4] Kanagaraj J, Sastry P, Rose C (2005) Effective preservation of raw goat skin for the reduction of total dissolved solids. Journal of Cleaner Production 13: 959-96.

[5] Bienkiewiez K (1983) Physical chemistry of leather manufacture. RE Krieger Publishing Company, Florida, USA.

[6] Schillinger U, Lucke FK (1987) Identification of Lactobacilli from meat and meat products. Journal of Food Microbiology 4:199-208.

[7] Lucke FK (2000) Utilisation of microbes to process and preserve meat. Meat Science 56: 105-115.

[8] Nair PS, Surendran, PK (2005) Biochemical characterization Of Lactic Acid bacteria isolated from fish and prawn. Journal of Culture Collections 4: 48-52.

[9] Lengkey HAW, Balia RL, Togoe I, Tasbac BA, Ludong M (2009) Isolation and identification of lactic acid bacteria from raw poultry meat Biotechnology. Animal Husbandry 25: 1071-1077.

[10] De Vuyst L, Leroy F (2007) Bacteriocin from lactic acid bacteria: Production, purification and food application. Journal of Molecular Microbiology and Biotechnology 13: 194-199.

[11] Senthilvelan T, Kanagaraj, J, Mandal AB (2012) Application of enzymes for dehairing of skins: cleaner leather processing. Clean Technology and Environmental Policy 14: 889-897.

[12] Tagg JR, Dajani A, Wannamaker LW (1976) Bacteriocin of gram positive bacteria. Bacteriological Revision 40: 722-755.

[13] Upreti GC, Hinsdill RD (1973) Isolation and characterization of a bacteriocin from a homo fermentative Lactobacillus. Chemosphere 4: 117-121.

[14] Eaton AD, Clesceri LS, Greenberg AE (1995) Standard methods of the examination of water and waste water. The American Public Health Association (APHA), Washington

[15] Lengkey HAW, Balia RL, Togoe I, Tasbac BA, Ludong M (2009) Isolation and identification of lactic acid bacteria from raw poultry meat Biotechnology. Animal Husbandry 25: 1071-1077.

[16] Dorothy M (1995) The characteristics of Lactobacillus plantarum, L. helveticus and L. Casei. Journal of General Microbiology 12: 133-139.

[17] Nagao J, Aso Y, Shioya K, Nakayama J, Sonomoto K (2007) Lantibiotic engineering: Molecular characterization and exploitation of Lantibiotic- synthesising enzymes for peptide engineering. Journal of Molecular Microbiology and Biotechnology 13: 235-242.

[18] Armenti KR, Moure-Eraso Slatin V, Geiser V (2011) Primary prevention for worker health and safety: cleaner production and toxics use reduction in Massachusetts. Journal of Cleaner Production 19: 488-497.

[19] Clevaland J, Montvilla TJ, Nes IF, Chikindas M (2002) Bacteriocins: Safe, natural antimicrobial for food preservation. International Journal of Food Microbiology 71: 1-20.

[20] De Vuyst L, Calleweart R, Crabbe K (1996) Primary metabolite kinetics of bacteriocin biosynthesis by Lactobacillus amylovorus and evidence for stimulus of bacteriocin production under unfavourable growth conditions. Microbiology 142: 817-827.

[21] Lindgren SE, Dobrogosz WJ (1990) Antagonistic activities of lactic acid bacteria in food and feed fermentations. FEMS Microbiology Reviews 8: 149-164.

[22] Schunerer A, Mgnusson J (2005) Antifungal lactic acid bacteria as biopreservatives. Trends in Food Science \& Technology 16: 70-78.

[23] Lejeune R, Calleweart R, Crabbe K, De Vuyst L (1999) Modeling the growth and bacteriocin production by Lactobacillus amylovorus DCE 471 in batch conditions. Journal of Applied Microbiology 65: 5358-5356.

[24] Leroy F, Devuyst L (2005) Simulation of the effect of sausage ingredients and technology on the functionality of the bacteriocinproducing Lactobacillus salcei CTC Lc94 strain. Interenational Journal of Food Microbiology 100: 141-152. 
[25] Cai SY, Takeda Y, Yoshida T, Tays T, Nakase T (1998) Chracterization of Leuconostoc species isolated from vacuumpacked ham. Journal of General Applied Microbiology 44: 153159.

[26] Heunis TDJ, Botes M, Dicks LMT (2010) Encapsulation of Lactobacillus plantarum 423 and its bacteriocin in nanofibers. Probiotics and Antimicrobial Proteins 2: 46-51.

[27] Lengkey HAW, Balia RL, Togoe I, Tasbac BA, Ludong M (2009) Isolation and identification of lactic acid bacteria from raw poultry meat Biotechnology. Animal Husbandry 25: 1071-1077.
[28] Rogne P, Fimland G, Meyer JN, Kristiansen PE (2008) Threedimensional structure of the two peptides that constitute the twopeptide bacteriocin lactococcin. General Biotech Biophysics Acta 1784: 543-554.

[29] Khan IV, Ahmad A, Khan AS, Yusuf M, Shahid M, Manzoor N, Mohammad F (2011) Assessment of antimicrobial activity of Catechu and its dyed substrate. Journal of Cleaner Production 19: 1385-1394.

[30] Prusty AK, Das T, Nayak A, Das NB (2010) Colorimetric analysis and antimicrobial study of natural dyes and dyed silk. Journal of Cleaner Production 18: 1750-1756. 